\title{
'Tavern' by the Saltpan: New England Seafarers and the Politics of Punch on La Tortuga Island, Venezuela, 1682-1782
}

Konrad A. Antczak

College of William \& Mary - Arts \& Sciences

Follow this and additional works at: https://scholarworks.wm.edu/etd

Part of the Latin American History Commons, and the Social and Cultural Anthropology Commons

\section{Recommended Citation}

Antczak, Konrad A., "'Tavern' by the Saltpan: New England Seafarers and the Politics of Punch on La Tortuga Island, Venezuela, 1682-1782" (2014). Dissertations, Theses, and Masters Projects. Paper 1539626753.

https://dx.doi.org/doi:10.21220/s2-nc8j-kr90

This Thesis is brought to you for free and open access by the Theses, Dissertations, \& Master Projects at W\&M ScholarWorks. It has been accepted for inclusion in Dissertations, Theses, and Masters Projects by an authorized administrator of W\&M ScholarWorks. For more information, please contact scholarworks@wm.edu. 
'Tavern' By the Saltpan: New England Seafarers and the Politics of Punch on La Tortuga Island, Venezuela, 1682-1781

Konrad A. Antczak

Caracas, Venezuela

B.A., Rollins College, 2011

\begin{abstract}
A Thesis presented to the Graduate Faculty
of the College of William and Mary in Candidacy for the Degree of Master of Arts
\end{abstract}

Department of Anthropology

The College of William and Mary January 2014 


\title{
APPROVAL PAGE
}

This Thesis is submitted in partial fulfillment of the requirements for the degree of

\author{
Master of Arts
}

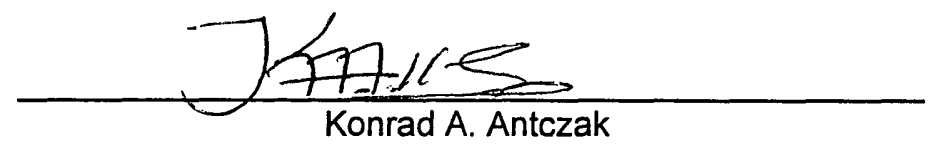

Approved by the Committees May, 2014

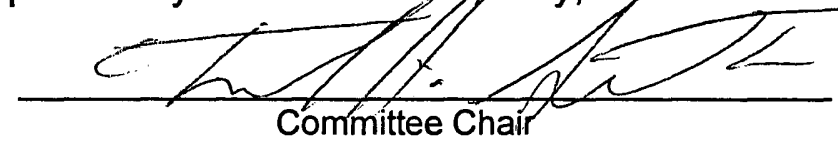

Associate Professor Frederick Smith, Anthropology

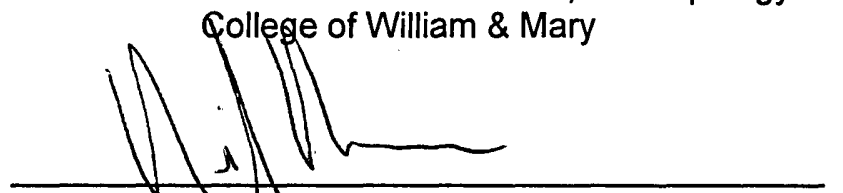

Assistant Professor Neil Norman, Anthropology

College of William \& Mayy

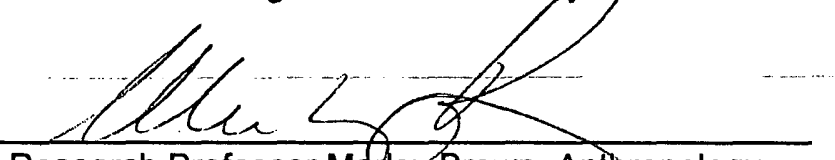

Research Professor Manley Brown, Anthropology

College of William \& Mary 


\begin{abstract}
New England seafarers from small merchant ships visited the natural saltpans of the Venezuelan island of La Tortuga from the late seventeenth century up until 1781. The liminal space of the island set the stage for the creation of an improvised 'tavern' where the communalism of shipboard life was suddenly changed to more markedly vertical relations. Drawing from archaeological excavations and original documentary sources it is argued that, while on land, captains no longer worked alongside their crews who now labored extracting salt. With leisure time available to them, punch drinking offered captains a means of discursive practice through the manipulation of fashionable material culture and an opportunity to negotiate their social position among peers. When given to the crew, punch served as a labor incentive and a way of obfuscating the sudden change in customary captain-crew relations while on the island.
\end{abstract}




\section{TABLE OF CONTENTS}

Acknowledgements

Dedication iii

List of Figures iv

$\begin{array}{ll}\text { Introduction } & 1\end{array}$

Chapter 1. Geographical setting and historical background 2

Chapter 2. Power relations onboard small eighteenth-century New England merchant ships $\quad 5$

Chapter 3. La Tortuga as a liminal space $\quad 9$

Chapter 4. The punch bowls and their archaeological context 12

$\begin{array}{lll}\text { Chapter 5. Captains and the punch they imbibed } & 18\end{array}$

Chapter 6. Punch bowls as receptacles of social lubricant 22

$\begin{array}{lll}\text { Chapter 7. Punch for the laboring crews } & 27\end{array}$

$\begin{array}{ll}\text { Conclusion } & 30\end{array}$

$\begin{array}{ll}\text { Bibliography } & 38\end{array}$ 


\section{ACKNOWLEDGEMENTS}

I want to thank my parents for having given me the 'keys' to La Tortuga and for their tireless and steadfast efforts in getting me on this path. I want to recognize and thank Reinaldo Breidenbach, Ali Kohler, Rafael Strubiher and Carlos Rivero for their invaluable support and companionship in the field. My gratitude goes to José Miguel Pérez Gómez and Alberto Boscari for their logistical and financial support in many fieldwork campaigns. A special thanks to John Austin for sharing his knowledge on English delftware with me and providing much insight in its analysis. I want to thank Andrzej Antczak, Frederick Smith, Neil Norman, Marley Brown, Patrick Johnson and Andy Beaupré for revising and offering comments on various drafts of this thesis. Saving the most important for last, I want to thank Valerita. 


\section{For Valerita}




\section{LIST OF FIGURES}

1. Map of the Caribbean 31

2. La Tortuga Island and the site of Punta Salinas in the southeastern corner

3. Punta Salinas with the saltpans at the top and Los Mogotes Lagoon to the right (photo: José Miguel Pérez Gómez)

4. Map of the Punta Salinas site (TR/S)

5. English delftware punch bowls from Punta Salinas

6. From left to right, top to bottom: English white salt-glazed, creamware, "scratch blue", New Hampshire black leadglazed red earthenware and Derbyshire/Nottingham brown stoneware punch bowls from Punta Salinas

7. Other artifacts from the Dunes activity area. From left to right, top to bottom: German stoneware mineral water jug, melon-ware teapot from Staffordshire, glass tumbler, Chinese porcelain dish, English delftware plate, English white salt-glazed stoneware plate, lead dice, Spanish silver cob, pewter sundial 


\section{Introduction}

La Tortuga, an unassuming Venezuelan island, became the scenario for intensive salt exploitation during the seventeenth and eighteenth century. This uninhabited and peripheral Spanish island was a one-of-akind space within the Anglo-American sphere of commerce in the Caribbean. Its unique characteristics set the stage for the creation of the ephemeral equivalent of a tavern that was the most common meeting place for sailors in the main Caribbean ports. The La Tortuga 'tavern' was a specific place where the captains of small New England ships would gather annually while their crews were collecting salt on the adjacent saltpans. This paper proposes that in this 'tavern' by the saltpan, 145 archaeologically recovered punch bowls-the receptacles of punch-became key players in social politics and material discourse of New England captains.

The methodology used here includes the formal analysis of the bowls, the analysis of their archaeological contexts and the reconstruction of the social context of their use, all juxtaposed with comprehensive research of primary documentary sources. It will be argued that for the captains, punch bowls and punch were a means of displaying fashionable tastes, negotiating social status and creating strategic social alliances. Captains employed punch as an incentive for their crews laboring on the saltpans and a safety vent to assure productive and efficient salt exploitation. Moreover, the material entanglements of the exotic punch and the fashionable punch bowls-brought from the far-reaches of the Anglo-American sphere of commerce-reflected the cosmopolitan sensibility of the captain and seaman in the burgeoning Atlantic World economy. The historical archaeology research on La Tortuga opens a new window onto the often elusive social and material lives of eighteenth-century New England seafarers. 


\section{Chapter 1: Geographical setting and historical background}

The Venezuelan island of La Tortuga, 100 kilometers northwest from the modern day port of Puerto la Cruz (Fig. 1), is approximately $25 \mathrm{~km}$ long and $10 \mathrm{~km}$ wide (Fig. 2). It is predominantly flat, with the exception of a calcareous terrace running along the southern coast, rising to nearly 45 masl (meters above sea level) (Maloney and Macsotay 1967, p. 267). This semi-arid island largely supports xeric scrubs, bushes and cacti that sparsely dot its hostile landscape. Only a few coastal areas have mangrove communities, one of them being the Los Mogotes Lagoon on the island's southeastern corner. There, the mangroves border the saltpans and the adjacent Punta Salinas archaeological site. The island has no permanent sources of fresh water, with there being only a few seasonal pools of rainwater. La Tortuga's salty riches, however, dwarfed these conditions uninviting to seventeenth- and eighteenth- century seafarers.

The saltpans of this Spanish island increasingly drew enterprising New England merchants during the second half of the seventeenth century. By 1682, when the English naturalist, explorer and privateer William Dampier paid a visit to the saltpans, they were already "much frequented [...] by Merchant Ships, that come thither to lade Salt" (Dampier 1699, p. 56). Although larger saltpans existed on the Caribbean islands (e.g., St. Martin, Anguilla, Curacao, and Grand Turk and Salt Cay in the Turks Islands) one aspect set La Tortuga apart (Huntley 1948) (Fig. 1). La Tortuga was uninhabited and thus unique among salt-producing islands of the Caribbean in complete lack of tenure rights, taxes and a local labor source (Gregory 1978, pp. 58-64, Jarvis 2010a, pp. 196-199). According to documentary sources, annually and for more than a hundred years, only the crews of New England merchant ships raked and bagged the salt on the island, resulting in higher profit margins than a salt-run to other Caribbean islands could yield (Antczak et al. 2011; Council of Trade and Plantations to Lord Bolingbroke, 1714). 
The treaties of 1667, 1670, 1715 and 1750 between Spain and Great Britain allowed and ratified Anglo-American salt exploitation on La Tortuga (Hertslet 1878, pp. 82, 87). La Tortuga salt was not indispensable to the economy of the Province of Venezuela (after 1777 the Capitanía General de Venezuela) as abundant salt producing areas were available on the adjacent mainland, especially on the Araya Peninsula. Previous to the Anglo-American period, the Spanish had managed to oust the Dutch from a short-lived salt enterprise on La Tortuga in the 1630's. No treaty could, however, impede Spanish corsair ships-guarda costas hailing from Venezuela-from intercepting English vessels at La Tortuga, under the pretense that these were engaging in illicit trade and contraband. In response to this threat, the merchant population of New England pleaded the English crown for an armed escort of at least one British Navy ship to convoy their ships to and from the island (Governor, Council and Assembly of the Massachusetts Bay to the Queen, 1713). The earliest known La Tortuga Fleet-or Saltertuda Fleet as it was called in documentary sources-was arranged under the governorship of Sir Edmund Andros during his short tenure as Governor of the Dominion of New England in 1687 (Edmund Andros to Samuel Pepys). From 1687 to 1768 , there is documentary evidence that the fleet, escorted by a Navy vessel, sailed at least 30 times. In 1781 Spanish corsair Vicente Antonio Icuza appeared on the island and confiscated the salt from an American salt fleet (Amezaga 1966, p. 94). The saltpans of Punta Salinas were not raked by foreigners again after this incident, producing a reliable terminus ante quem of 1781 for the archaeological deposits.

According to documentary sources, the fishing port of Salem dominated the late seventeenthcentury salt fleets to La Tortuga. Boston rapidly overtook the salt exploitation on the island at the turn of the eighteenth century, resulting in more than double the number of ships calling to Boston back from La Tortuga than Salem. Soon many other ports of the Anglo-American Atlantic world, such as New York, Philadelphia, Newport, Piscataqua (Portsmouth, New Hampshire), New London and also Bermuda were involved in the La Tortuga salt exploitation and trade. The analysis of the Naval Officer Shipping 
Lists for Boston, Salem, Piscataqua and New York and eighteenth-century Anglo-American newspapers shows that between 1700 and 1775918 ships came to the aforementioned New England ports, loaded with salt from La Tortuga (Antczak et al. 2011).

Merchant ships headed to La Tortuga would usually leave the New England coast in early December and would congregate on Barbados between December and January. Once the Saltertuda Fleet had gathered, and a British Navy ship was ready for escort, they set sail for La Tortuga in midJanuary. Upon arrival at the island, the saltpans were divided up according to ship burthen and, depending on the weather, the crews could rake salt for more than a month, often waiting for salt to crystallize on the pans multiple times (Brownrigg 1748, pp. 24-28). Once the holds of ships were filled up with salt, the fleet would sail up through the Windward Passage, and north of Bermuda the ships would disperse, each to its home port (Fig. 1). In late April and early May of nearly every year, these ships arrived from La Tortuga with the salt necessary for the New England spring fisheries (Pares 1963, p. 631). This salt was used to cure refuse cod which was shipped back to the Lesser Antilles to feed the enslaved Africans of sugar plantations, primarily Barbados, providing them with a staple source of protein (Innis 1940, pp. 76-78; Publications of the Colonial Society of Massachusetts 1927, p. 241). 


\section{Chapter 2: Power relations onboard small eighteenth-century New England merchant ships}

The merchant ships that came to La Tortuga to load salt were relatively small vessels. Tonnage figures derived from analysis of the abovementioned Naval Officer Shipping Lists indicate that the average burthen of the ships that are recorded to have arrived to New England from La Tortuga between 1700 and 1775 was 55 tons. In comparison to the much larger three-masted ocean-going vessels-upwards of 150 tons in burthen-crossing the Atlantic frequently, the ships arriving at La Tortuga were in their majority small schooners, sloops, and brigantines. The Naval Officer Shipping Lists indicate that most had 7 seafarers onboard, including the captain and mate. These small crew sizes played a significant role in creating a division of labor that was not as clear-cut and strict as on larger ships of the English merchant marine and the British Navy which had hundreds of men and a taut hierarchy onboard (Rodger 1986).

On small ships, the captain was the sole commander. Captains were responsible directly to the merchants that had hired them to manage the navigation, voyage, cargo, and seamen on a ship (Rediker 1987, p. 84). They delegated labor to the crew and imposed discipline, but also had the obligation of provisioning the crew with food and drink and exercising due care over their welfare (Jarvis 2010b, $\mathrm{p}$. 90; Vickers 2005, p. 222). The mate was an officer who marshaled significantly less power onboard than the captain and occupied the position of second in command. His duty was to set the men to work, keep them in good order, maintain the ship functioning properly and oversee the other of the two watches (Rediker 1987, p. 84). The common seaman was at the bottom rung of labor division of the ship. Seamen were divided into the two shifts and carried out physical labor at sea as well as in ports during the loading and unloading of cargoes. When off duty, the seaman had free time that he could dedicate towards recreational activities such as drinking, eating, storytelling, mending clothes, and sleeping (Vickers 2005, p. 91). 
In order to understand the power relations of ship captains and their crews once they disembarked on the Punta Salinas site, the ship hierarchy and captain/crew relations on the small ships that brought these seafarers to the island must be further discussed. Considerable debate amongst maritime scholars centers on the figure of the captain, his power and authority and his social and economic distancing from the crew. Marcus Rediker (1987, pp. 84, 241) insists that the system of maritime authority was largely based on coercion and violence. Rediker (p. 209) does, however, concede that crew size affected relations of authority and small American ships had less necessity for physical discipline. Other maritime scholars such as Daniel Vickers (2005), Peter Earle (1998) and Michael Jarvis (2010b) place less emphasis on violence and conflict, although they recognize that chastisement and corporal punishment were legal and part of life and work on the deep, as long as these were communally accepted. They suggest that tyranny onboard was not universal and the powers of a captain over his crew were primarily circumscribed by scale-the lesser the size of the ship and the smaller the number of seamen, the stronger the communal and familial affiliations amongst the crew and the less physical violence a captain could apply (Earle 1998, p. 163; Jarvis 2010b, p. 81; Vickers 2005, p. 225). Captains on these small ships would indeed exercise their authority in alternative ways that were not necessarily violent. One of these ways might have been the paternalistic distribution of alcohol, especially to their crews laboring on the saltpans of La Tortuga.

Living in close quarters, a small crew size and the sharing of common tasks, activities and dangers contributed to the general collectivism onboard most ships sailing to La Tortuga. Outside of the menial seaman's tasks such as pumping the bilge, knotting yarns for rope or scrubbing the deck, captains often worked together with the crew in tasks that accompanied regular shiphandling such as "setting, reefing, trimming and taking in sails, steering the vessel, as well as repairing rigging and canvas" (Vickers 2005, p. 90). Moreover, captains not only shared many of the manual tasks with their crews, but also the same or similar leisure activities, rations and general living space (Jarvis 2010b, p. 
86). The captain and mate probably had their own cabins on the ships visiting La Tortuga, but these were cramped and offered limited privacy. It is probable that at times captains and mates did not partake in regular manual tasks, yet it would be a stretch of the imagination to consider that a rigid hierarchy developed on board these small ships, where captains became total commanders and managers, aloof of any physical work (Jarvis 2010b, p. 86; Vickers 2005., pp. 90-91).

According to Rediker (1987, p. 243), collectivism on board merchant ships in the eighteenth century was separated into two broad categories. The first was a vertical collectivism of the entire ship, created by a shared confrontation with nature and need for survival. The second was a horizontal collectivism amongst the crew formed from the conflict caused by the social relations of waged labor. This class conflict, however, is fully applicable to much larger ships, where social distinction, rank and hierarchy could be understood through considerable spatial distinctions on ship (the quarterdeck and the forecastle) and a greater division of labor and thus a greater separation of the captain and seamen (Vickers 2005, p. 225). As Jarvis argues, Rediker dwells on the tension and sharp social distinctions between officers and seamen that existed on large merchant and navy ships, unlike the small merchant ships "where the highly personal level of constant interaction and considerable potential for advancement worked against such differentiation" (Jarvis 2002, p. 605).

On board small ships this vertical collectivism in many ways merged with the horizontal. Once the captains anchored in the bay of Punta Salinas and disembarked for their multiple-week-long stay, this spatially enforced integration and collectivism onboard translated to a more distanced spatial segregation of the working seamen and the captains managing their labor. Captains would no longer partake in manual labor but, rather primarily manage the labor of their crews; they now had sufficient time on their hands for a certain degree of leisure. It is uncertain what role the mate played in this new scenario, but perhaps as the trusted subordinate to whom the captain delegated much of the 
responsibility for the crew's work and organization, he was the person more directly involved in the overseeing of the labor on the saltpans, and thus did not partake in all of the leisure activities of captains (Jarvis 2010b, p. 82). I argue that it was on the liminal space of Punta Salinas that the captains of these small vessels, accustomed to collectivism onboard, consciously changed the customary social relations of shipboard work and became total commanders and managers, distancing themselves from the arduous and backbreaking manual labor of salt exploitation. 


\section{Chapter 3: La Tortuga as a liminal space}

The anthropological concept of liminality was defined by Arnold van Gennep (1960) and was further developed by Victor Turner $(1967,1969,1974)$. In recent years the concept of liminality has been reevaluated and applied more broadly to landscapes, seeking to expand beyond ritual practices and psychosocial processes (Andrews and Roberts 2012, p. 6). In 2012 a session at the Society for Historical Archaeology meeting in Baltimore was dedicated to the historical archaeology of liminal spaces, places and statuses. Drawing from these more recent conceptualizations of liminality as it relates to space, 1 consider that La Tortuga was a liminal space in the Atlantic World and that the liminal character attributed to this island permeated the activities that the New England seafarers developed there.

La Tortuga was a liminal space situated on the borderland of the Anglo-American sphere of commerce in the Caribbean and as literary scholars Hein Viljoen et al. (2004, p. 18) explain, "The liminal space ties in strongly with the concept of boundaries, because the liminal space comes into existence at the border of that which is found at the center and that which belongs to the periphery." Peripheral La Tortuga, the southernmost Caribbean island to which the Anglo-Americans sailed, was a Spanish possession. The Anglo-American seafarers arrived to La Tortuga from having stopped at a populated English Barbados to find a large but uninhabited island. The 400 mile passage westward from Barbados to La Tortuga brought the seamen into waters marauded by Spanish corsairs and, even though they might have been escorted by a British Navy ship, when the seafarers disembarked on La Tortuga they entered a dangerous space. Threat loomed as the physically absent Spanish could menacingly materialize on ships at any moment of the day or night.

The geo-political particularities of this liminal island were combined with the phenomenologically traceable hostile environmental factors of the sojourn and work. During the dry season months when the seafarers arrived to La Tortuga, the island's inclement sun reflecting off of the 
white sands, the sweltering heat and the constant torment of mosquitoes and sandflies affected both the captains and crews (for other contemporaneous examples of the latter see Atkins 1735, p. 227 and Dow and Edwards 1973, p. 248). Seamen raked the saltpans, bagged the salt and loaded it onto the ships in the bay, toiling and laboring under aggressive environmental conditions which were exacerbated by the burning effects of exposure to salt, in a manner similarly experienced by salt rakers in other parts of the Caribbean (Jarvis 2010a, p. 198; Kennedy 2007, p. 215). In unison, these factors would have furthered the shared notion that La Tortuga was indeed a no-man's-land-a final frontier of Anglo-American maritime incursion in the Caribbean.

La Tortuga was not only a peripheral space on the frontier of the Anglo-American sphere of commerce, it was also a borderland of the Spanish Province of Venezuela. Being liminal in spatial, political and economic terms, La Tortuga also stood as an ambiguous space in social and ideological terms-one that had to be reconstituted by the captains and crews of New England vessels. The ambiguity of Spanish La Tortuga is perhaps most evident by its more than 132 English exonyms in seventeenth- and eighteenth-century Anglo-American documentary sources (e.g., 'Saltertuda, Salt Tatuga and Saltatoodos) most of which derive from "Salt Tortuga" - the combined English and Spanish name for the island. Philip Sheldrake (2001, p. 91) argues that, "Living on some kind of physical boundary symbolizes a state of liminality-of living between two worlds." Although in this case Sheldrake uses liminality to describe the boundaries between the two worlds of the material and the spiritual, when this conception of a binary oppositions is transposed to the liminal space of La Tortuga, a series of site-specific oppositions arises. The Punta Salinas site occupied the ambivalent border between land and sea, and the island was a borderland, betwixt and between the Spanish and English spheres of influence-politically belonging to the first, but economically being exploited by the latter. 
The seafarers, caught in between these oppositions on the liminal space of Punta Salinas, had to improvise, innovate and create their own temporary world. The lack of a built environment, one tamed and constructed by humans, amplified La Tortuga's liminal character. According to geographer Yi-Fu Tuan (1977, p. 102) the built environment-as opposed to nature's raw stage-clarifies social roles and relations. The social roles of the constrained wooden environment of the ship were suddenly exposed on the naked and raw stage of Punta Salinas, were there was no built environment, and more pressingly for the seafarer-there was no tavern.

Cultural historian John Mack (2011, p. 165) elaborates on the behavior changing potential of liminal spaces and considers ports as the scene of behaviors that are distinctively different from those practiced on board ships or further inland. La Tortuga was, however, no ordinary port-of-call. The AngloAmerican social actors that disembarked onto the liminal and ambiguous space of Punta Salinas were placed in a liminal state and engaged in this setting in social relations that were distinctively different from those practiced aboard ship and in any typical Atlantic World tavern. Unlike onboard their small ships, the captains did not work here for weeks, but rather leisurely oversaw and managed the labor of their crews on the saltpans. In this setting the many captains who yearly visited the island sought to set up a temporary 'tavern' on Punta Salinas, where on one hand the social relations and the politics of material discourse-specifically punch bowls-were used for their purposes of sociability and, on the other hand, alcohol was used to attenuate the now apparent rift in what was not long before a collectivism of captain and crew. 


\section{Chapter 4: The punch bowls and their archaeological context}

The Punta Salinas archaeological site (TR/S) is approximately 5.6 hectares in area (c. $200 \times 280$ meters). The saltpans extend to the site's north and run more than a kilometer eastward towards the coast (Fig. 3). The site comprises an area of sandy plain with the maximum elevation in low sand dunes rising to some 1.4 masl (meters above sea level) on the north (Fig. 4). A survey was conducted in 1992, extensive shovel and test pit excavation in 1993 and systematic trench excavations in 2009 and twice in 2010. During the five field seasons at Punta Salinas more than $30(1 \times 1$ meter) test pits were arbitrarily excavated, primarily where surface scatters of artifacts and ecofacts were identified. These pits helped delimit the boundaries of three activity areas: the Dunes (TR/S/D), Fringe (TR/S/F) and Barracks (TR/S/B) (Fig. 4). Trenches excavated in these activity areas contained a high density and wide array of eighteenth-century ceramics, glass, metal artifacts and zooarchaeological remains suggesting that throughout the $18^{\text {th }}$ century seafarers concentrated their leisurely activities here. Outside of these activity areas, the Punta Salinas site exhibits a remarkable horizontal dispersion and very low density of objects per square meter, making it difficult to conduct extensive open-area excavations.

The excavations at Punta Salinas revealed a minimum number of 145 punch bowls. These were defined according to the Potomac Typological System (Beaudry et al. 1988, p. 63). Fifty-six of these are creamware. Of these, two are peculiar punch bowls dating to the 1760's (David Barker personal communication, 2012) with rouletted cable bands on the rim and on the foot ring and vertical fluting on the body, possibly skeuomorphs of similarly decorated fine silver punchbowls (Fig. 6) (Connell 1957, p. 10). One creamware punch bowl is a polychrome hand-painted example. There are a minimum number of 50 English delftware punch bowls. Many of these punch bowls originated in London, several in Bristol and at least two in Liverpool and most of them date to between 1720/1730 and 1750 (Fig. 5) (Archer 1997; Austin 1994; Britton 1982; John Austin personal communication, 2010; Lipski 1984). The forms of the bowls are characteristic of this period of greatest delftware production from the English factories 
being deeper and less broad at the rim, with shorter foot rings than the late examples from the 1760 s and 1770s (Archer 1997, p. 9; Hume 1969, pp. 107, 125; Shlasko 1989, p. 84). Only one bowl is datable to the later production phase (post-1760) and is probably from Liverpool.

Further punch bowls are represented by English white salt-glazed stoneware ( 23 minimum vessels), New Hampshire black lead-glazed red earthenware (7 minimum vessels), Derbyshire /Nottingham brown stoneware ( 5 minimum vessels), and "scratch blue" ( 4 minimum vessels). Punch bowls represent 40.1 percent of the ceramic tableware assemblage of 362 minimum vessels recovered at Punta Salinas. This percentage figure from La Tortuga stands out as unusually high when compared to Eleanor Breen's analysis of 38 archaeological sites from the East Coast of the United States and the Caribbean where punch bowls were recovered $(2012$, p. 86-87). Of these the highest percentage figure comes from the late phase of Shields Tavern in Williamsburg, Virginia (1738-1751), which contained 54 punch bowls, representing 29.8 percent of the ceramic tableware assemblage (181 minimum vessels) (Brown et al. 1990, p. 99). Punta Salinas falls amply within Kathleen Bragdon's (1988) characterization of a tavern by having a high percentage of drinking vessels (punch bowls, mugs/tankards, tea bowls, cups, drinking glasses, glass tumblers and glass mugs) with a minimum number of 273 , comprising 65.2 percent of the total 419 minimum number of ceramic and glass tablewares.

The punch bowls from the Punta Salinas site are relatively small and portable, perfectly suited for stowing in a sea chest-a characteristic indispensable to a seafarer's mobile lifestyle. They fall within Anne Yentsch's (1991, p. 65) category of small bowls used for consumption-as opposed to larger bowls used for serving. Such small handheld delftware punch bowls were commonly termed 'sneakers' in the eighteenth century, and could be found in various taverns around the Atlantic for those drinkers that did not have the money or company to share a larger bowl with (Harvey 2008, pp. 207, 219). Some of the smaller delftware bowls from Punta Salinas may have been tea bowls, and indeed the smallest with a 
diameter of $8 \mathrm{~cm}$ was not included in the statistics. Delftware tea bowls seem to range in diameter between 6 and $8 \mathrm{~cm}$ (Archer 1997, pp. 349-351; Brown et al. 1990, p. 185). The total average diameter of the punch bowl fragments that could be measured is of $15.3 \mathrm{~cm}$, compared to the average diameter of more standard punch bowls studied by Michael Archer (1997, p. 283) which was of $30.5 \mathrm{~cm}$. The smallest punch bowl was $11 \mathrm{~cm}$ in diameter and the largest $24 \mathrm{~cm}$ (the 10 delftware punch bowls found at the Rumney West Tavern in London Town, Maryland, fell within a similar range of diameters [Luckenbach 2002, p. 146]).

The volumes of Punta Salinas' punch bowls are also reflective of their use not as communal bowls, but as individual drinking vessels, from which punch was probably directly consumed, evoking the growing individualism with the advent of the Georgian worldview in the mid-eighteenth century (Deetz 1996; Leone 1988; Leone 1999; Rice 1983, p. 98). The largest punch bowl has an approximate volume of 420 milliliters and the smallest $193 \mathrm{ml}$, with an average of the measurable bowls being a volume of $268.1 \mathrm{ml}$. Four quarts of punch (almost four liters) were required to fill a large communal punch bowl in an Anglo-American tavern (Rice 1983, p. 95). On la Tortuga the delftware punch bowls, on average, held close to half a pint ( 1 pint $=550.58 \mathrm{ml}$ [Ross 1983, p. 39]) when filled near the brim. These small bowls stand as paltry in comparison to the multi-liter behemoths oftentimes used at merchant elite parties in the eighteenth century (Archer 1997, p. 283; Gollannek 2008, pp. 202-203).

So far, these vessels have been referred to as punch bowls, but it can be validly posited that they might have as well been multi-purpose vessels used for the consumption of soups and pottages as well as drink. To answer this issue we must return to the archaeological assemblage of which these delftware punch bowls are a part. The delftware assemblage from Punta Salinas consists of a minimum number of 105 vessels; 34 percent of these vessels are plates, 15 percent include wide-rimmed dashed bowls, a saucer and a jug and the remaining 51 percent are punch bowls. The creamware assemblage 
consists of a minimum number of 107 vessels of which 35 percent are plates, 14 percent are tankards, mugs, a saucer and a teapot and the remaining 51 percent are punch bowls. These percentages, and the variety of vessel types, make it highly probable that vessel form indeed defined function in most cases on the Punta Salinas site. Providing that this assumption is correct, then plates were used for eating, the wide rimmed-bowls probably for consumption of stews and soups and the tankards, mugs and punch bowls for drinking. It is also important to underline that as Harvey $(2012$, p. 177) suggests, "the material culture of punch drinking crossed these material lines of demarcation", and punch could have also been ladled from bowls and drank from glass tumblers ( 46 minimum vessels) and stem glasses ( 2 minimum vessels) found at Punt Salinas.

The Dunes activity area stands out as the richest archaeological context in which 23 delftware, 26 creamware, 14 English white salt-glazed and 2 "scratch blue" punch bowls were recovered (Fig. 6). The two large trenches (TR/S/D-1 and D-2) excavated here, yielded a breadth and variety of material culture that suggests that the temporary occupants of this area repeatedly brought and used in this place artifacts of economic, personal and social value, among these objects used for leisure activities. Three lead die, a fighting cock tarsometatarsus with spur and 47 silver Spanish cobs suggest that the typical eighteenth-century tavern activities of gambling and cockfighting where happening on the Dunes activity area (Brown et al. 1990; Rice 1983). A wide array of tablewares including English white salt-glaze and creamware plates, Chinese porcelain tea bowls, Whieldon melon- and cauliflower-ware teapots and copper-wheel engraved Bohemian glass tumblers were also recovered here (Fig. 7).

A brick-lined fire pit, the only permanent feature contextually attributable to the AngloAmerican period of exploitation at Punta Salinas, was found at the northeastern end of trench TR/S/D-1 in the Dunes activity area (Fig. 4). It consisted of a bed of bricks and coral stones placed directly on the sand with a semicircle of coral stones forming a protective wall from the wind. The sand at the base of 
the fire pit was darkened with charcoal and carbonized organic matter. To the south of the fire pit patches of faunal remains were recovered, including local species such as West Indian top shell (Cittarium pica), porgies (Calamus sp.), snappers (Lutjanidae), groupers (Epinephelidae), grunts (Haemulidae), jacks (Carangidae), parrotfish (Scaridae) and bones of allochthonous animals such as pigs and cows. Various fragments of the inferior maxilla of pigs suggest that the people gathered on the Dunes might have been consuming pork jowl, with the head and cheek being prized pieces of meat in the eighteenth century (Glasse 1774). Faunal remains and punch bowl fragments were lying in the sheer sand of the dune at a depth between 20 and $40 \mathrm{~cm}$, while the base of the fire pit was at a depth of 45 to $50 \mathrm{~cm}$. It can be reasonably assumed that the cooking activities that were taking place here were functionally associated with the discard of the punch bowls and other artifacts and ecofacts.

Documentary evidence suggests that sitting on land might have been customary for the captains at Punta Salinas as a letter relating the arrival of the Scarborough Man of War, commanded by Capt. Gregory in March of 1768 recounts,

\footnotetext{
"Captain Gregory then sent his lieutenant on shore, to acquaint all the captains of the vessels, that all their salt should be taken from them [...] About two o'clock captain Gregory, with one of the masters under his convoy, came on shore himself and repeated to us the same things" (Political Register and Impartial Review of New Books 1768, p. 90).
}

The Dunes activity area, situated on the most elevated portion of the Punta Salinas site, would have offered its occupants the best vantage point from which to view and oversee the crews working on the saltpans and the surrounding areas and also enjoy the best sea breeze. A small pewter sundial, a gilded key from a mechanical pocket watch and two bottles from what was possibly a sand hour may indicate that the captains spending their leisure time on the Dunes were interested in timekeeping for the purposes of managing their crews' labor. These findings echo Mark Leone's (1988, p. 242) interpretation of clocks and watches in the eighteenth century as elements of the "Georgian conceptual order", segregating, subdividing and focusing on order and social control. Also, the recovery of two lead sheets 
with circular token pre-forms stamped into them, along with various circular lead tokens, may suggest that these were either temporary substitutes for future payments or gaming pieces. This concentration of items of economic and personal value, and artefacts and ecofacts associated with gaming and gambling at the Dunes, suggests that the activity area was largely and repeatedly occupied by the most economically adventurous members of New England ships-namely captains.

Outside of taverns (Bragdon 1988; Brown et al. 1990; King and Miller 1987; Luckenbach 2002), historical archaeologists have mostly studied punch bowls from the households and plantation homes of the elite and the wealthy in the Atlantic World (Beaudry 2010; Goodwin 1999; Smith 2001; Smith 2008; Yentsch 1990; Yentsch 1994). The archaeology of punch drinking among people of middling and lower socio-economic status has not received the same attention. Ship captains would have had greater access than regular crewmembers to resources and goods at ports, and would have been, in many ways, arbiters of fashionable taste, always 'in tune' and aware of the latest trends in England. Moreover, while on land on La Tortuga, the captain would interact with many of his peers-captains of ships much like himself-in a setting of close interaction that might have spurred the need to distinguish himself from the rest of his crew (and other crews), and also assert his position among the masters of the other vessels. The people using the punch bowls and imbibing punch on La Tortuga were non-elite-they were captains and crews of small ships. Indeed, in terms of social interactions, 'something' different was occurring on La Tortuga, 'something' that was not commonly replicable in any other city, town, port or household in the Anglo-American Atlantic world. 


\section{Chapter 5: Captains and the punch they imbibed}

On La Tortuga, seafarers had no permanent physical tavern in which they would accustom to spend their leisure time in other Caribbean and Atlantic World ports. Constrained and enabled by the liminality of the island's space, captains repeatedly improvised and recreated an open-air tavern on Punta Salinas. The port in Bridgetown (Barbados) from which the ships sailed directly to La Tortuga, had more than one tavern for every 30 residents (Smith and Watson 2008, p. 79). In 1682, English privateer and naturalist William Dampier (1699, p. 56) recounts the popularity of punch drinking on La Tortuga,

\footnotetext{
"I have seen above 20 Sail at a time in this Road [La Tortuga] come to lade Salt; and these ships coming from some of the Caribbe Islands, are always well stored with Rum, Sugar and Limejuice to make Punch, to hearten their Men when they are at work, getting and bringing aboard the Salt; and they commonly provide the more, in hopes to meet with Privateers, who resort hither in the aforesaid Months, purposely to keep a Christmas, as they call it; being sure to meet with Liquor enough to be merry with, and are very liberal to those that treat them."
}

Punch was a cornerstone of the later seventeenth- and eighteenth-century seafarer's drinking practice (Harvey 2012, p. 194). It is a mixed drink consisting of five ingredients-hence the name "punch" most probably derives from the Hindustani panch meaning five (Connell 1957, p. 1; Grigsby 2002, p. 176; Smith 2005, pp. 80-81). The ingredients varied in many seventeenth and eighteenth-century recipes but, generally included spirit (rum, brandy and arrack) or wine, fruit (limes, lemons or oranges), sugar, spices (usually nutmeg) and water (Goodwin 1999, p, 131; Rice 1983, p. 95). Punch has been traditionally ascribed an Oriental origin, nonetheless, there is a strong claim that it was actually an English creation, having originated onboard seventeenth century ships travelling to the Orient and traversing the vast Pacific, Indian and Atlantic oceans (Gollannek 2008, p. 164; Harvey 2012, p. 173-174; Wondrich 2010, p. 37).

For the wealthy, punch could contain rare grated nutmeg, exotic pineapples and fine French brandy or Madeira wines (Nathan 2006, p. 32). There were also various forms of sugar that could be used in punch, from simple and unrefined brown muscovado to a highly-refined and expensive white 
powdery sugar (Gollannek 2008, p. 189). Moreover, large delftware and porcelain punch bowls and their accompanying accessories such as elaborate silver punch ladles, fancy nutmeg graters and fine glass stemware made punch a preferred showy drink among the gentility, whether Barbadian planters or New England Merchants (Connell 1957; Goodwin 1999; Smith 2005, p. 123). Nonetheless, many of these items might have been more easily available to seafarers, as they were the very people who made them accessible to the gentility by way of their ships (Harvey 2012, p. 194). For example, fresh drinking water would have been a luxury aboard ship and the minimum number of 91 German stoneware mineral water jugs recovered at Punta Salinas (some or many of these might have been reused for other liquids) are a prime example that even water, the most inconspicuous ingredient in the making of punch, could be exotic on La Tortuga where no fresh water could be found.

Punch, that "quintessential Atlantic world beverage" as art historian Eric Gollannek (2008, p. 164) terms it, grew greatly in popularity in the late seventeenth and eighteenth century and became a drink of which people of all social classes came to partake (Harvey 2012, p. 180). The maritime origins of punch were evident in multiple ways. In the mid-eighteenth century in Britain, decorated "success" or "presentation" punch bowls in delftware, salt-glazed stoneware and other wares were commissioned by captains as testimonials of business friendships and often had the recipient's ship and name painted on the interior (Archer 1997, pp. 308-309; Rudolph 1985, pp. 42-43). Clearly, punch was popular among the seafarers (both captains and crews) on La Tortuga when Dampier visited the island in 1682. Indeed, punch was primarily consumed by the middling classes, of which seafarers were a large portion in the late seventeenth and eighteenth century (Harvey 2012, p. 180).

Rum punch offered a distinct local option to those who could not purchase finer imported spirits. It was made on the basis of rum that was plentiful in the Caribbean and New England and, especially, in the case of the Saltertuda Fleet, it was readily available on Barbados, the gathering point for the last leg of the Fleet's voyage to La Tortuga (Smith 2005) (Fig. 1). Limes were also readily available 
on Barbados, and were renowned for producing abundant juice (Singleton 1767, pp. 23-24). Lime juice in punch supplemented the mariner's miserable and nutrient-deficient diet by providing him with an essential source of vitamin C to counter the threat of scurvy on long voyages (Watt 1981, pp. 57-58). Sugar, the Barbados' prime export, was also readily available to the ships sailing from the island to La Tortuga.

The 1766 inventories of three Bermudian ships apprehended by Spanish corsairs while raking salt on La Tortuga clearly show that at least two of the ingredients for punch were carried onboard. The brigantine Porgey had 40 gallons of rum (enough to fill 640, 1/2 pint punch bowls!), 4 gallons of "old spirit" (presumably old rum), a keg of brandy, 4 dozen bottles of porter, 1 dozen of wine, 40 pounds of white sugar and 2 punch ladles (Minutes of His Majesty's Council, Bermuda, pp. 206-207). The brigantine Roach had similar stores, including a "China Bowle", the $18^{\text {th }}$ century term associated with punch bowls (Minutes of His Majesty's Council, Bermuda, p. 209). Two ships arriving at Piscataqua via Barbados and Saltertuda (La Tortuga) on May 25 and 28, 1765, carried salt, rum and 50 gallons of lime juice each, which the naval officer describes as stores (Naval Officers' Lists of Shipping). In spite of the naval officer's description it is doubtful that such a large quantity of lime juice was solely ship stores, nonetheless, it is possible that it was put to good use in the making of punch while on La Tortuga.

The fluidity of movement that New England captains exhibited to ports in the circum-Atlantic was a contributing factor to the presence of fashionable objects-among them punch bowls-at the Punta Salinas site. Barbados was also a prime port for acquiring fine goods, as traveler and clergyman of the Dominican order Jean-Baptiste Labat (1979, pp. 207-208) noted by the end of seventeenth century that "The traders' shops and warehouses [in Barbados] are filled with desirous items from all parts of the world" (authors translation). The access to the various ports and their goods may have also opened 
the possibility for acquiring commodities associated with punch consumption that did not preserve or leave markers in the archaeological record such as fine spices, aromatic bitters and various exotic spirits. 


\section{Chapter 6: Punch bowls as receptacles of social lubricant}

Unhindered by the four walls of a traditional tavern, primarily the captains - who had to supply their own crockery-had a unique opportunity on La Tortuga to display their possessions and exotic goods, whether they were punch bowls, plates and teapots, or spices, fine liquors and even fighting cocks. Through the manipulation of this material culture the captains, who had the most purchasing power from those onboard, could underscore their individuality. A greater emphasis on the individual, as evidenced by the personal and portable-not communal-delftware punch bowls, was, as previously mentioned, a part of the expanding Georgian worldview and also echoed the changes towards individual drinking preferences in New England taverns in the second half of the eighteenth century (Garvin and Garvin 1988, pp. 157-158; Rice 1983, p. 98). I maintain that on La Tortuga these bowls were portable status markers. A delftware punch bowl glazed and painted in bright colors and exotic Chinese motifs would have been an eye-catching and conversation-starting piece.

Although the crockery that the captains brought underscored their individuality, punch drinking was still a thoroughly communal affair. Punta Salinas offered a prime setting for both alcohol based masculine sociability and material culture discourse. The punch held within the delftware punch bowls was a social lubricant. Alcohol is commonly believed to function as an agent in fostering social interaction, communication, companionship, camaraderie, conviviality and sociability (Hawdon 2005, p. 177). Gollannek (2008, p. 213) describes the socially 'magnetic' role of the punch bowl and its contents as a social lubricant around which strangers felt at ease and information was shared freely. The role of punch on La Tortuga was no different amongst the captains carousing and limiting the monotony of waiting weeks-on-end by engaging in leisurely activities. The captains most surely found this unique opportunity to speak through-and let speak-the objects they brought, especially the delftware punch bowls, in order to differentiate themselves from one another and their crews. On Punta Salinas, the 
captains could set themselves apart from their crews and engage in a horizontal verbal and material discourse with other peers. The suppressed and attenuated desires of social distinction onboard the small merchant ships-where a generalized communalism prevailed-were temporarily let loose on the saltpans. Captains, however, knew they would inescapably return to life at sea.

The fashionable tastes of many captains and their access to the newfangled goods from England, the Atlantic World and beyond were most certainly driving factors for the acquisitive desire of the rest of the captains to seek and emulate the collections of their peers. Ian Woodward $(2007$, p. 158) summarizes that the tastes of one person are only meaningful in relation to those of others, where the force of these tastes at once becomes socially integrative and differentiating. As Lorinda Goodwin (1999, p. 119) argues, the "craze for novelty might have arisen from a desire to stand out (in a favorable sense) from a crowd of dedicated consumers." To Goodwin (1999, p. 119) refinement required the use of luxuries, which elevate the status of the practitioner. On Punta Salinas a captain's knowledge and possession of fashionable and novel 'things' and the display of their accompanying manners of handling and use (associated to expressions, gestures and poses) would be essential to demonstrating knowledge and wealth through material culture. All those who were similarly versed in these dealings became part of a group creating a competitive yet convivial fraternal atmosphere.

Consumption (knowledge) and shopping (competence) were an important social act in the hands of particular actors with particular agendas, and among these agendas were group politics (Cook et al. 1996, p. 60). A telling account in 1814 of the shopping impulses of captains comes from a captain from Holstein by the name of Smidt upon his visit to Newcastle,

"I stopped at each store to admire the splendid goods which were displayed. Nothing can be more seductive than this kind of rich shop-windows... With difficulty I resisted the temptation to spend my all of seven half-crowns on some of this colorful bric-a-brac; however, a portion of my hoard was sacrificed and I became the owner of a few decorated mugs and cups. My purchases were knotted into my kerchief and I resumed my promenade up and down the streets, bearing my treasure most gingerly" (quoted in Rudolph 1985, p. 73). 
Ashley Bowen, an eighteenth-century seaman from Marblehead, Massachusetts, recounts that his captain, Peter Hall "was a man so well acquainted in luxury [...] he must make as grand show as possible of his abilities" (Vickers 2006, p. 47). Although probably Smidt and, certainly, Hall were captain of considerably larger and more hierarchically structured ships than those that arrived to Punta Salinas, their taste for luxurious goods was probably similarly shared by other captains of the eighteenth- and nineteenth-century Atlantic World.

The captains that had access to these goods were in a way emulating the mannerly behavior of the merchant elite in New England and the affluent drinking parties they hosted with fine delftware drinking wares and accompanying paraphernalia (Goodwin 1999, pp. 135-138). However, as Goodwin (p. 134) suggests, perhaps the mannerliness of the captains consisted in setting aside the polite distance and detachment of elite society and replacing it with communal drunkenness. The captains that brought with them the delftware punch bowls sought to engage in discursive practice. They drank with fellow captains and by manipulating their material possessions-among which the punch bowl filled with punch played the preeminent role-they became integrated into the temporary community of the 'tavern' by the saltpan and could reaffirm or increase their social standing among their peers. Conversely, those captains that did not have the means of acquiring and displaying their own articles of conspicuous consumption might have been left out of this competitive environment and could not negotiate their status accordingly.

These leisurely weeks of tropical tedium on La Tortuga would also have served as moments to create future social networks and strategic alliances, and build friendships that might lead to greater social mobility for particular individuals. To Michael Dietler (2010, pp. 222-223) the performative aspects of alcohol consumption, which have been discussed above in relations to punch bowls and the paraphernalia of punch drinking, serve in the construction of social and personal identity and the 
creation and maintenance of social relationships and politics-something that would have been of great importance to the captains carousing on La Tortuga. Although his stay on La Tortuga might have not been of significant influence on his future career, William Whipple, the signer of the Declaration of Independence as a representative of New Hampshire, captained the brigantine Elizabteh of Piscataqua loaded with to and from Tortuga in 1756 (Naval Officers' Lists of Shipping; Ward 2012, p. 59). Furthermore, the captains of many of the ships that arrived to the island in the eighteenth century were also owners or part-owners of the vessels they managed.

The convivial gathering of captains on the Punta Salinas site would have also involved exchanges of information, news and gossip. The captains indeed exhibited great solidarity and camaraderie in the face of a common threat, as the account of the confiscation of their salt by Captain Robert Gregory of the Scarborough Man of War in March of 1768 exemplifies. The captains rallied to stop the 'illegal' confiscation of their salt, however, upon failing to do so promised to prosecute Captain Gregory in court in New England (Political Register and Impartial Review of New Books 1768, pp. 90-93; Boston NewsLetter, April 30, 1768). As has been evidenced by the aforementioned archaeological evidence from the Dunes activity area, besides drinking, captains were probably also engaging in the typical tavern activities of gambling and cock-fighting (Brown et al. 1990, p. 53; Rice 1983, p. 111). Toasting and health-drinking, important rituals in Anglo-American taverns, were most probably also occurring on the site, further fostering the sense of temporal community among the captains (Goodwin 1999, pp. 131, 137; Rice 1983, p. 98).

The punch bowl was an object of eighteenth-century material culture that metaphorically synthesized the Atlantic World. The eye-catching delftware bowls filled with exotic punch became the focal point of the social gathering of captains. Their materiality, however, transcended their role as integral components of discursive practice in the mediation of social relations on Punta Salinas. Punch itself-a blend of alcohol, fruit, water, spice and sugar-suggested as well the coming together of 
disparate people in the convivial act of drinking (Harvey 2012, p. 191). Punch bowls and punch became a potent metaphor of the far-reaching tentacles of the growing British mercantile capitalist world order; they became as Gollannek (2008, p. 220) describes them "supercharged space[s] for the sensory consumption of empire." It was through these fashionable objects that the captains could underscore their cosmopolitan identities and their connections to far-flung places of the Atlantic World and beyond. 


\section{Chapter 7: Punch for the laboring crews}

Punch served a twofold purpose on the Punta Salinas site. In the eighteenth-century alcohol was considered conducive both to relaxation and sociability-as primarily the case of the captains-but also, on the other hand, it prepared men, gave them strength and made them able to work (Garvin and Garvin 1988, p. 154). The role of alcohol as a labor incentive and enhancer has been studied by various authors (e.g. Dietler 1990; Dove 1998; Jankowiak and Bradburg 2003; Karp 1980; Suggs 2003), however, the cases addressed by these authors do not relate to situations where the laborers were paid wages, but rather to the mobilizing, enticing and incentivizing of labor through the distribution of alcohol in feasts. I hypothesize that on La Tortuga the alcohol given by captains to their crews-who were waged laborers - did not function within such a framework of feasting, but was rather an act of paternalism.

Crews performed better under toilsome conditions when they had the incentive of alcohol and captains capitalized on this knowledge. English cook Richard Briggs (Briggs 1788, p. 646) noted, “A great piece of aeconomy [sic] is the good management of small beer; for if that is not good, the drinkers of it will be feeble in summer time, incapable of strong work, and will be very subject to distempers." Thus as Dampier (1699, p. 56) recounted, many captains gave punch to their crews in hopes that it would "hearten" their men in the arduous process of salt exploitation and transportation to the ships, and thus utilized a form of power through alcohol distribution that was more subliminal than the outright employment of violence to control their men.

Some of the common notions of health and humoral medicine in the eighteenth century may have further spurred alcohol (especially rum) drinking in hot conditions such as those on La Tortuga. As British author Richard Ligon $(1673$, p. 27) reasoned "certain strong drinks are very requisite, where so much heat is; for the spirits being exhausted with much sweating, the inner parts are left cold and faint, and shall need comforting, and reviving [with more strong drinks]." Philadelphian Daniel Roberdeau 
(Rice 1983, p. 96) wrote in 1963, "In our extream Hot weather we cant do well with out Punch [sic]." Neville Connell argues that the tropical climate accounts for there being less seventeenth- and eighteenth-century accounts of drunkenness in the Caribbean, and that by sweating in the hot sun, drinkers were less prone to becoming intoxicated $(1957, \mathrm{p} .1)$. This is certainly true on La Tortuga, as the sweltering heat diminished the effects of excessive alcohol intake, as the author has observed among temporary fishermen during the fieldwork campaigns on the island.

The material evidence for the punch consumption of crews on the Punta Salinas site still needs to be further analyzed and discussed. The current study focuses on the Dunes activity area, however, the evidence from the remainder of the site needs to be drawn into this panorama. It can be suggested preliminarily, that during the eighteenth century, crews were gathered by more than 20 small fire pits of which only dark sand with carbonized matter and scatters of West Indian tops hell remain. Broadly, the artefacts associated with these features are among others, German stoneware mineral water jugs, green-glass bottles and creamware punch bowls, plates and mugs. Due to the fact that the site of Punta Salinas was visited over more than a century by hundreds of seafarers, it is an unattainable task to separate particular artefact scatters and activity areas from each other and determine their synchronicity.

On La Tortuga the workday of seamen was probably not constant. The arduous environmental conditions would have probably dictated a truncated workday, with the crews raking salt, bagging, transporting it to the shore and then to the ships in the bay, during the early mornings, late afternoons and possibly nights. In the late 16th century Spanish military architect Juan Bautista Antonelli (the Elder) noticed that the Dutchmen exploiting salt on the northeastern Venezuelan saltpans of Araya only worked during the early mornings and during moonlit nights in order to avoid the fatigue that came with working in the full tropical sun (Varela Marcos 1980, p. 77). The midday and other moments in the day 
when the seamen were not working offered an opportunity to drink and eat those rations that were allotted to them by their captains, and forage for those local resources they could collect from the sea and shoreline.

I hypothesize that captains paternalistically gave their crews larger rations than the customary onboard rations of alcohol or punch while they labored on the saltpans of La Tortuga. By incentivizing the work of the crews, alcohol also functioned as a safety vent-a means of veiling the now blatant line of labor division and social distinction drawn between the captains and crews on Punta Salinas. Indeed, through the distribution of punch, many seamen might have been diverted from understanding their new social situatedness on the island. The 'stage set' of the La Tortuga 'tavern' was, nonetheless, a temporary one, and the captains, 'actors' together with their 'props', would soon find themselves on their small ships in their routine social milieu. Only during the few weeks that the salt-raking enterprise on La Tortuga was underway could the captains engage in this 'theatrical' display of their material possessions, with their crews laboring and being appeased by providing them with alcohol-primarily in the form of punch. 


\section{Conclusion}

La Tortuga was a uniquely liminal space in the late seventeenth- and eighteenth-century AngloAmerican sphere of commerce in the Caribbean. The creation of a 'tavern' place on the Punta Salinas site, specifically the Dunes activity area, responded to the needs of the captains overseeing their crews laboring on the saltpans. Punch, a quintessentially maritime and English drink, became the focus of the drinking politics in the Punta Salinas 'tavern'. The temporality of the effects of punch as a social lubricant had to be capitalized by captains, for the horizontal social networks and strategic alliances that they formed while drinking and toasting together on the La Tortuga would endure beyond the 'salt run' and into the future. Furthermore, this 'tavern' gave enterprising captains a unique opportunity to show off their purchasing power through personal belongings-among them fashionable punch bowls filled with exotic ingredients-and in such a way negotiate their status among the many other captains gathered in this one place on La Tortuga.

When captains put punch into circulation among the crew it also helped to lessen the apparent vertical and hierarchical distinctions between those with authority (captains) and those laboring (crews) that surfaced while on La Tortuga. Further, this consumption decreased the possibilities of any irregularities, such as work stoppages, strikes and mutinies. It was after all in the captain's best interest that his crew perform optimally on the pans and rake salt as efficiently as possible. Alcohol in the form of punch was thus a powerful safety vent that assured that the crews would comply with the captains and do their jobs accordingly. It also obfuscated the disparity between the new-and now bluntly evident-power relations set up on the island and inhibited the capacity of the crew for a conscious awareness of their social situatedness. 


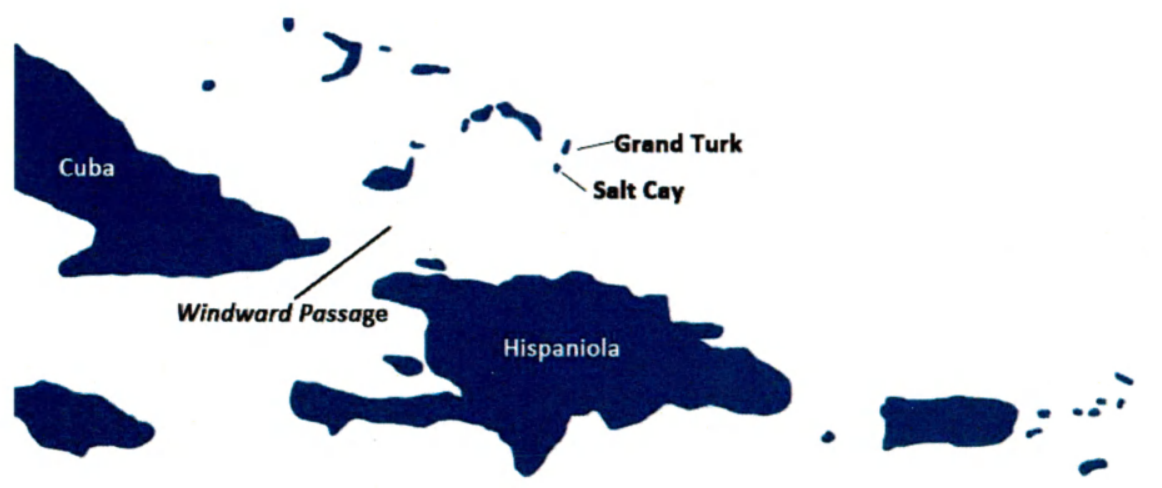

1

Caribbean Sea

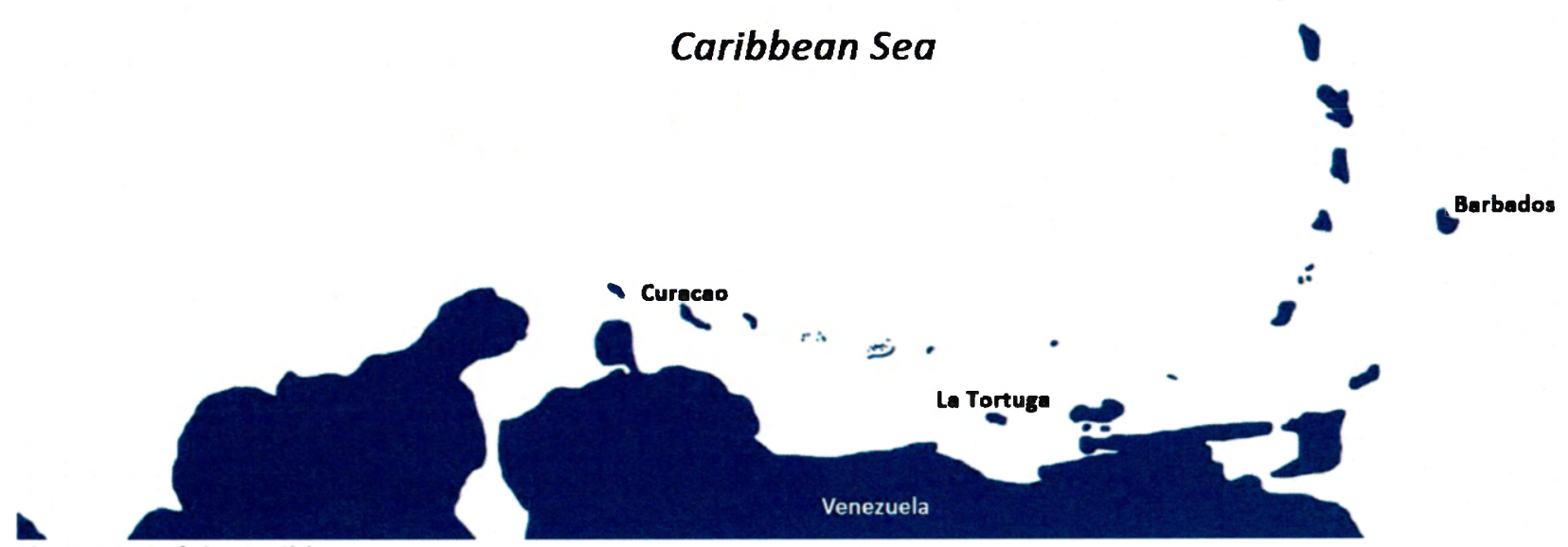

Fig. 1. Map of the Caribbean 


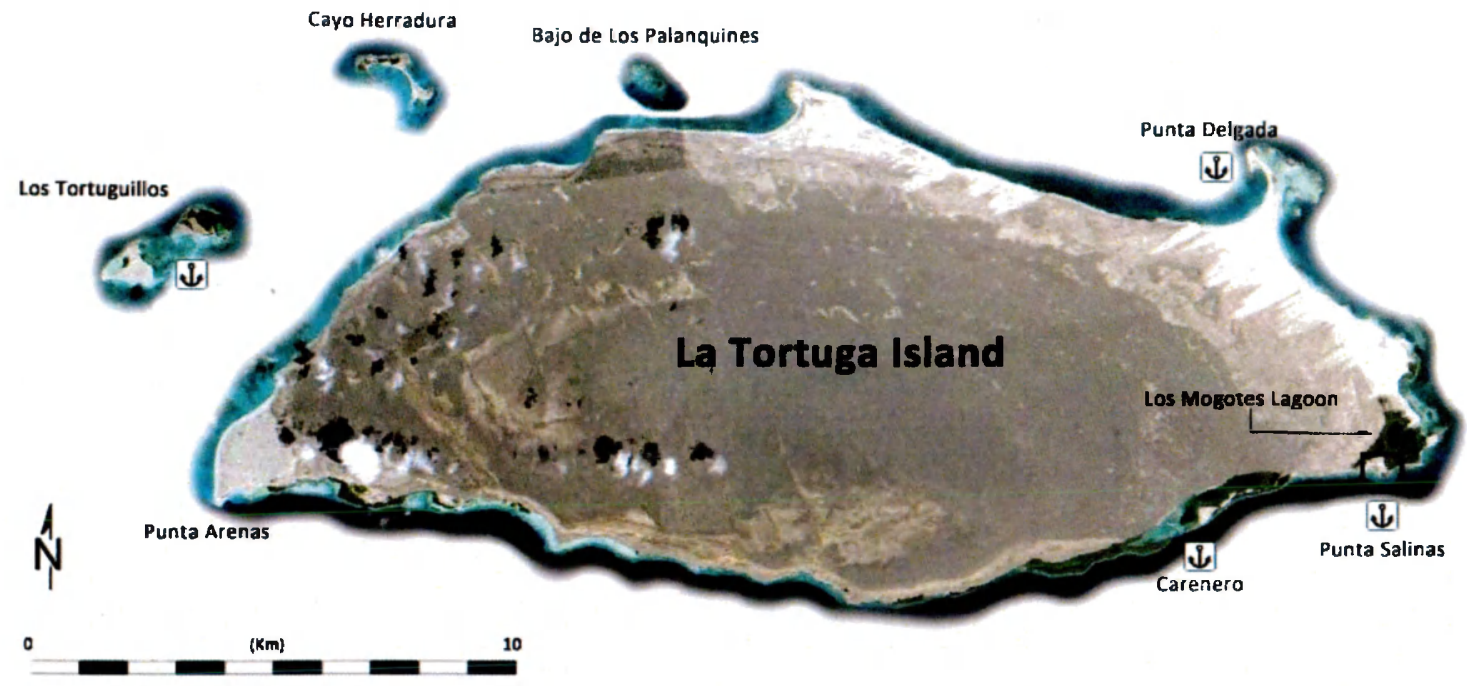

Fig. 2. La Tortuga Island and the site of Punta Salinas in the southeastern corner 


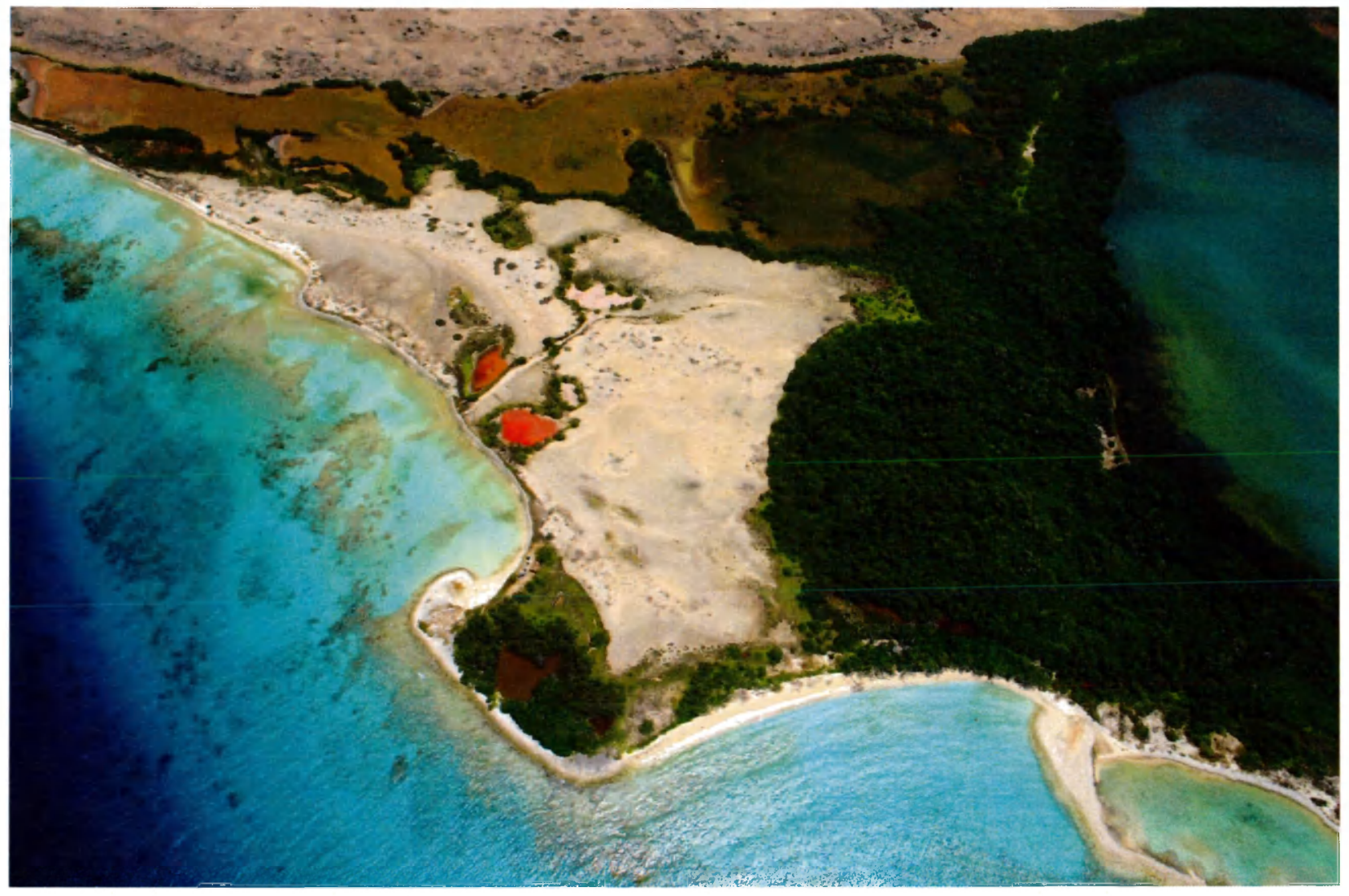

Fig. 3. Punta Salinas with the saltpans at the top and Los Mogotes Lagoon to the right (photo: José Miguel Pérez Gómez) 


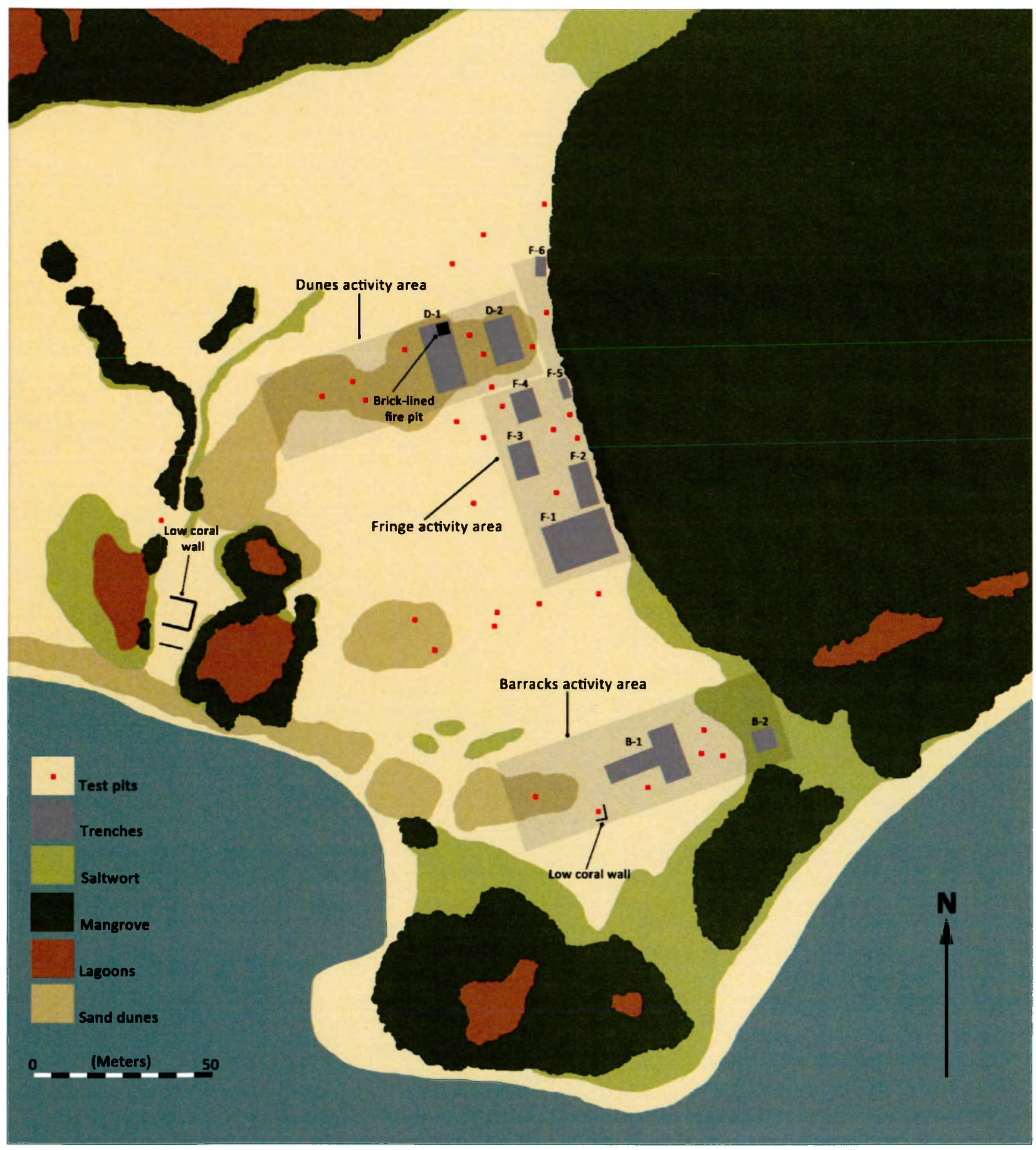

Fig. 4. Map of the Punta Salinas site (TR/S) 

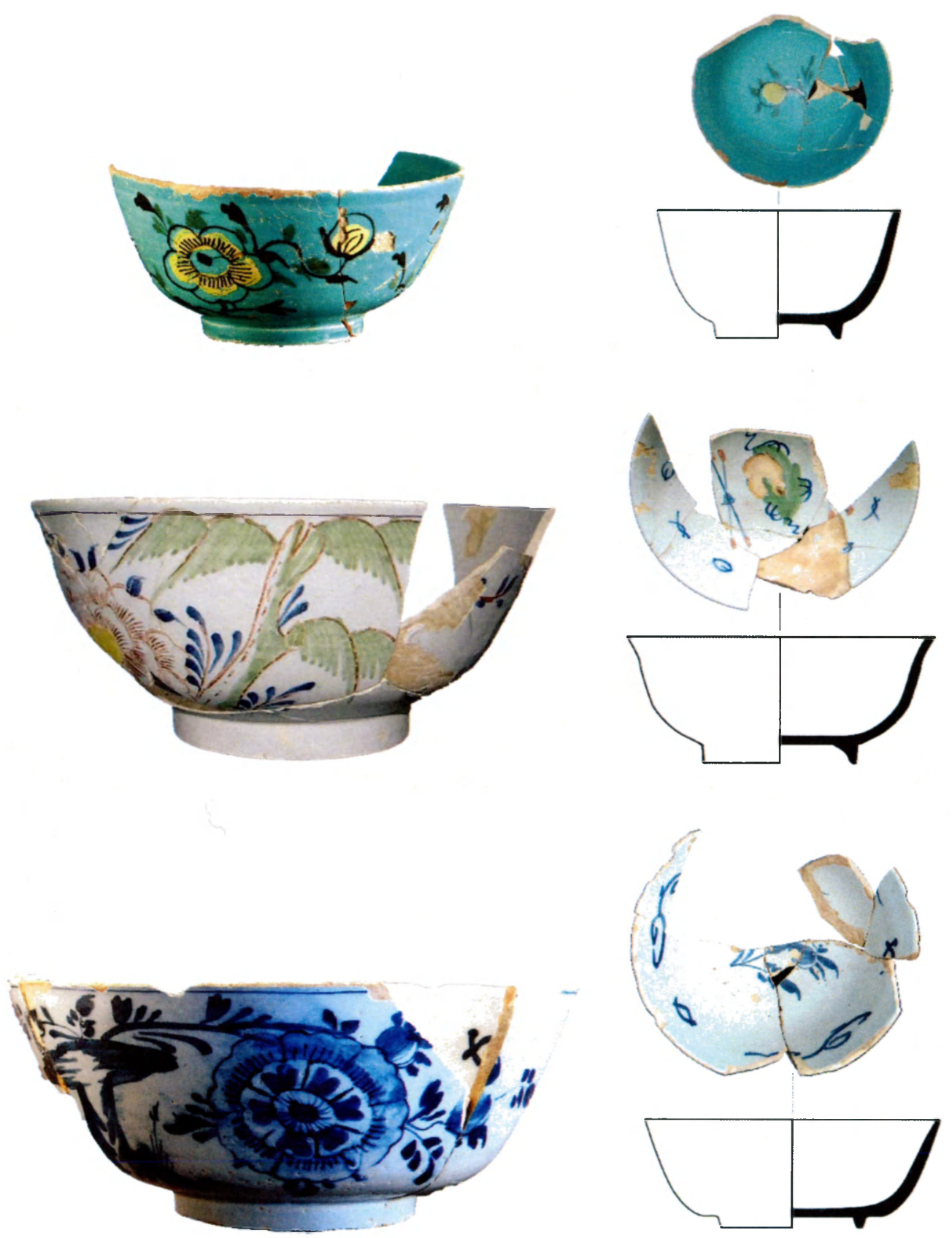

Fig 5. English delftware punch bowls from Punta Salinas 

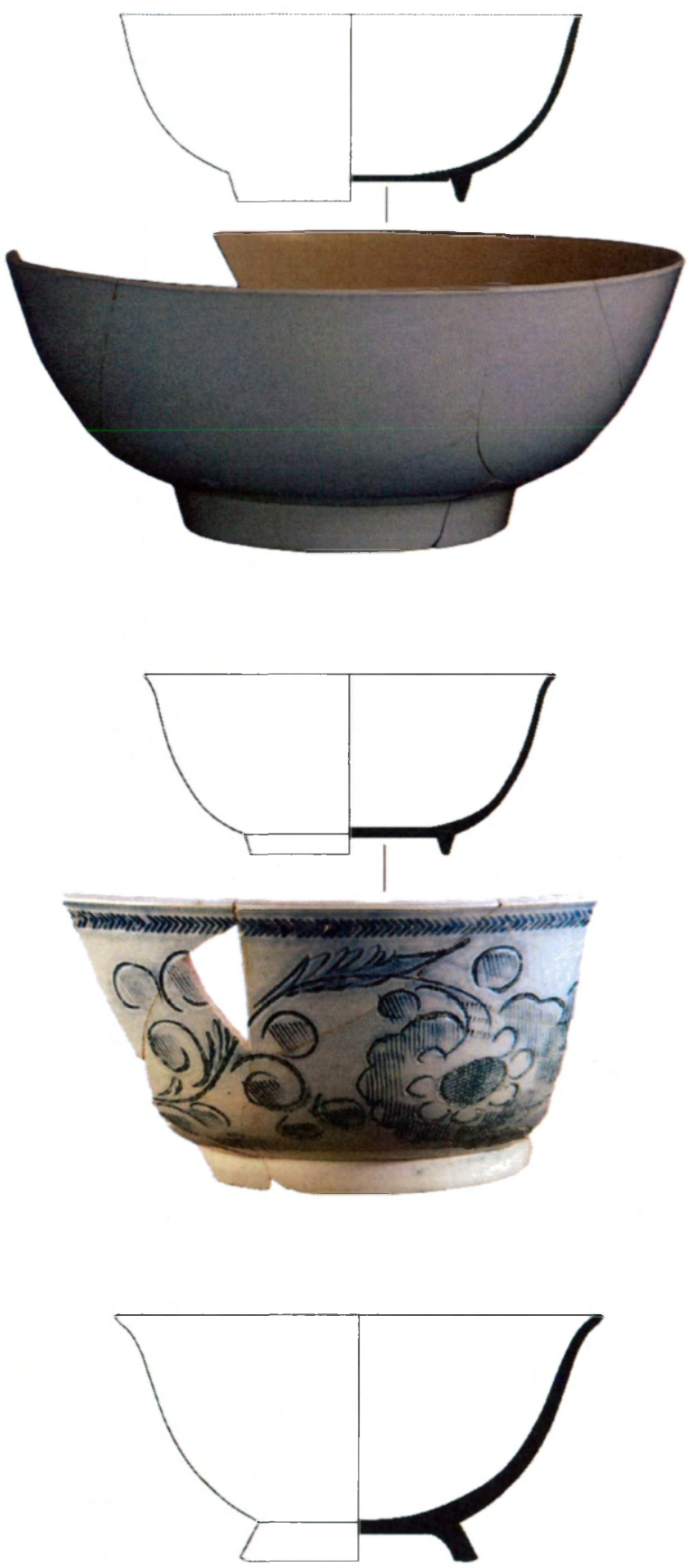
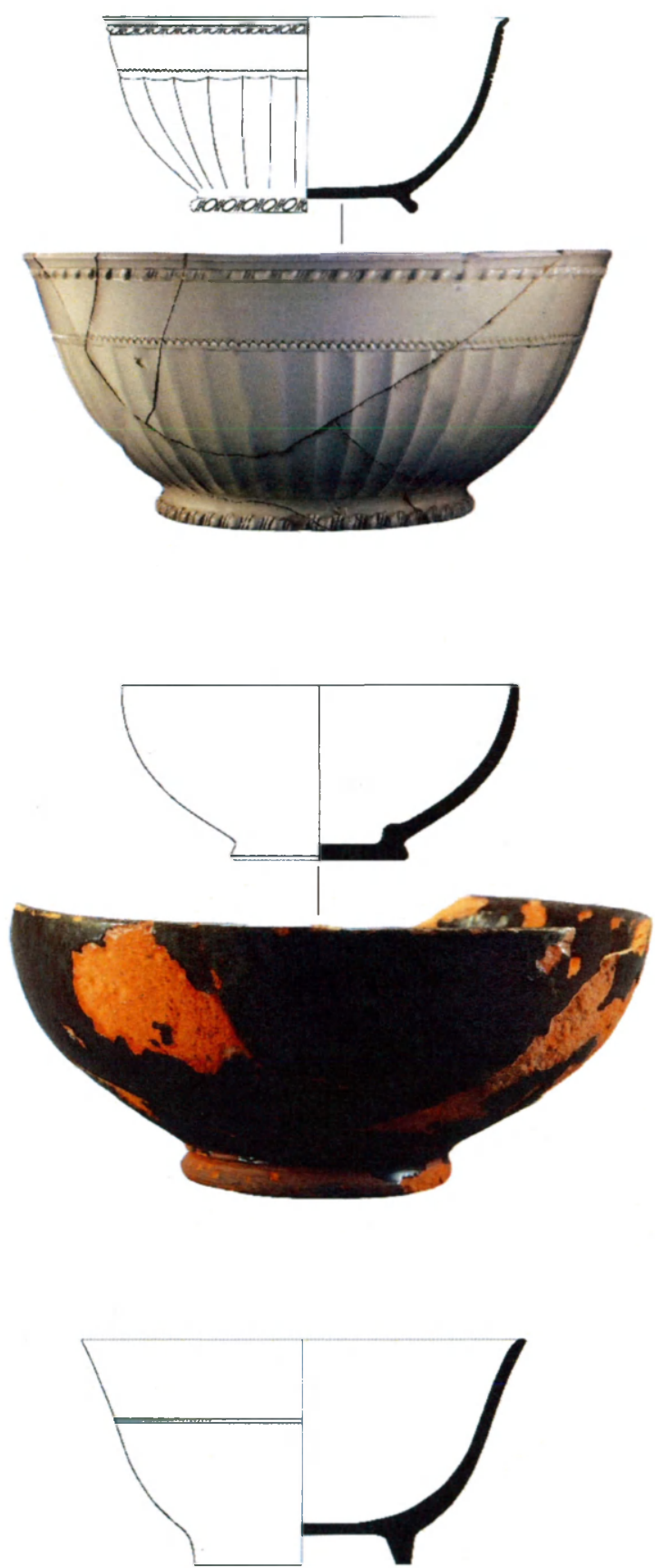

Fig. 6. From left to right, top to bottom: English white salt-glazed, creamware, "scratch blue", New Hampshire black leadglazed red earthenware and Derbyshire/Nottingham brown stoneware punch bowls from Punta Salinas 

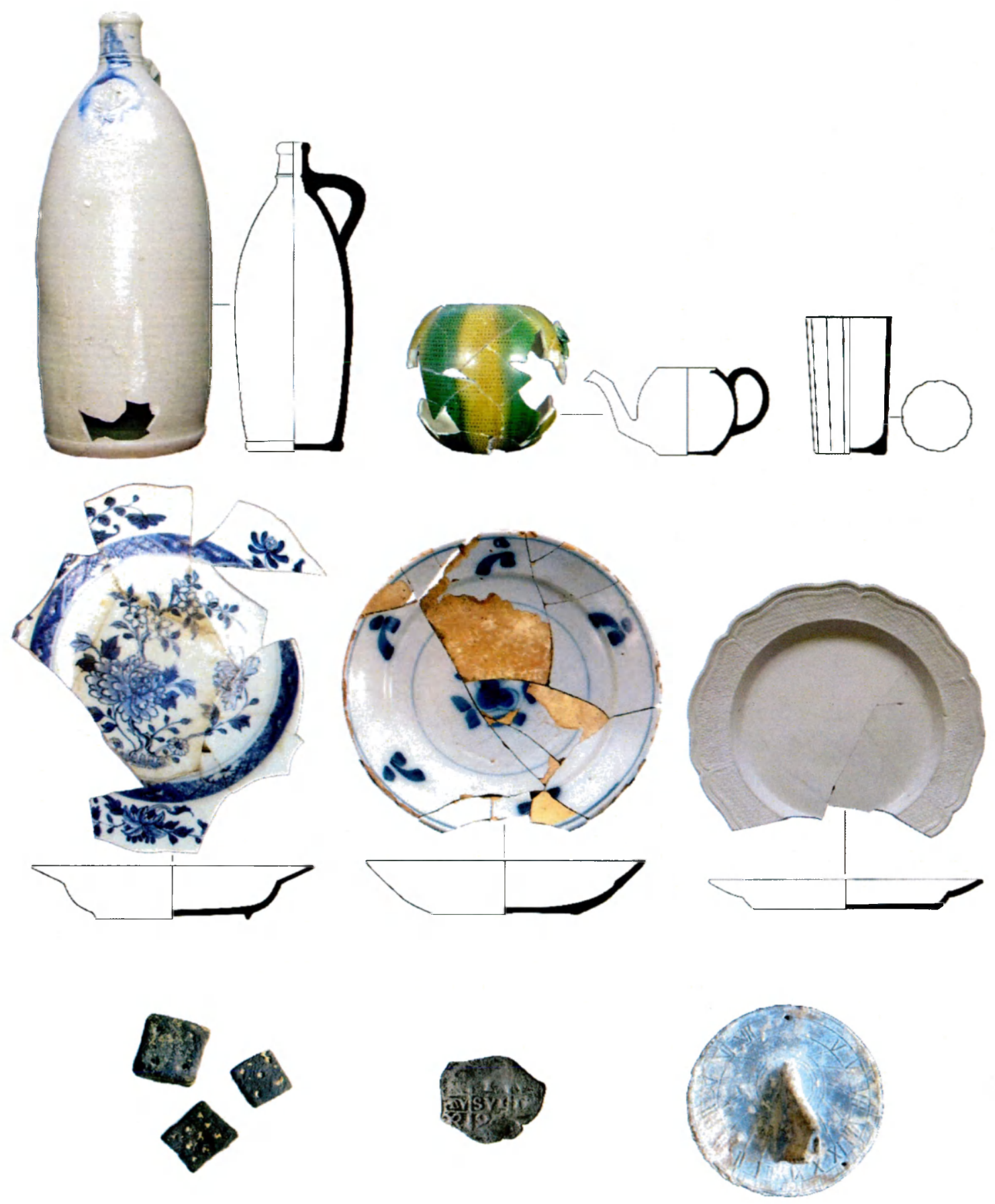

Fig. 7. Other artifacts from the Dunes activity area. From left to right, top to bottom: German stoneware mineral water jug, melon-ware teapot from Staffordshire, glass tumbler, Chinese porcelain dish, English delftware plate, English white saltglazed stoneware plate, lead dice, Spanish silver cob, pewter sundial 


\section{References}

Antczak, K., Antczak, A., Antczak, M. M., and Gómez, J. M. P. (2011). Historical archaeology of the 18thcentury Atlantic connections of La Tortuga Island, Venezuela. Paper presented at the 24th Congress of the International Association for Caribbean Archaeology, Fort-de-France, Martinique.

Andrews, H., and Roberts, L. (2012). Introduction: Re-mapping liminality. In Andrews, H. and Roberts, L. (eds.), Liminal Landscapes: Travel, Experience and Spaces In-Between, Routledge, London, pp. 1-18.

Andros, E. (June 30, 1687). Letter. [Governor Sir Edmund Andros writing to Samuel Pepys]. In [1899] Fortescue, J. W. (ed.), Calendar of State Papers, Colonial Series, America and West Indies, 16851688, London, pp. 467-468.

Archer, M. (1997). Delftware: the Tin-Glazed Earthenware of the British Isles, Victoria and Albert Museum, London.

Aresti, V. A. (1966). Vicente Antonio de Icuza Comandante de Corsarios. Italgráfica, Caracas.

Atkins, J. (1735). A Voyage to Guinea, Brazil and the West Indies: In His Majesty's Ships the Swallow and the Weymouth, London.

Austin, J. C. (1994). British Delft at Williamsburg, Colonial Williamsburg Foundation, Williamsburg.

Beaudry, M. C., Long, J., Miller, H. M., Neiman, F. D., and Stone, G. W. (1988). A vessel typology for early Chesapeake Ceramics: the Potomac Typological System. In Beaudry, M. C. (ed.), Documentary Archaeology in the New World, Cambridge University Press, Cambridge, England, pp. 51-67.

Beaudry, M. C. (2010). Privy to the feast: eighty to supper tonight. In Symonds, J. (ed.), Table Settings: The Material Culture and Social Context of Dining in the Old and New Worlds AD 1700-1900, Oxbow Books, Oxford, pp. 62-79.

Bragdon, K. (1988). Occupational differences reflected in material culture. In Beaudry, M. C. (ed.), Documentary Archaeology in the New World, Cambridge University Press, Cambridge, pp. 83-91.

Breen, E. (2012). One more bowl and then?: a material culture analysis of punch bowls. Journal of Middle Atlantic Archaeology 28: 81-97.

Briggs, R. (1788). The English Art of Cookery, According to the Present Practice; Being a Complete Guide to all Housekeepers, on a Plan Entirely New; Consisting of Thirty-Eight Chapters, London.

Britton, F. (1982). English Delftware in the Bristol Collection, Sotheby Publications, London.

Brown, G. J., Higgins III, T. F., Muraca, D. F., Pepper, S. K., and Polk, R. H. (1990). Archaeological Investigations of the Shields Tavern Site, Williamsburg, Virginia, Colonial Williamsburg Foundation Research Report, Williamsburg.

Brownrigg, W. (1748). The Art of Making Common Salt, London.

Cook, L. J., Yamin, R., and McCarthy, J. P. (1996). Shopping as meaningful action: towards a redefinition of consumption in historical archaeology. Historical Archaeology 30(4): 50-65.

Connell, N. (1957). Punch drinking and its accessories. The Journal of the Barbados Museum and Historical Society 25(1): 1-17.

Council of Trade and Plantations. (January 15, 1714). Letter. [Council of Trade and Plantations to Lord Bolingbroke]. Colonial Office 5/913, pp. 463-467. Archival material.

Dampier, W. (1699). A New Voyage Round the World, Volume I, Fourth Edition, London.

Dietler, M. (2010). Consumption. In Hicks, D. and Beaudry, M. C. (eds.), The Cambridge Companion to Historical Archaeology, Cambridge University Press, Cambridge, pp. 209-228.

Dietler, M. (1990). Driven by drink: the role of drinking in the political economy and the caste of early Iron Age France. Journal of Anthropological Archaeology 9: 352-406.

Deetz, J. (1996). In Small Things Forgotten: an Archaeology of Early American Life, Anchor Books, New York.

Dellino-Musgrave, V. (2006). Maritime Archaeology and Social Relations: British Action in the Southern Hemisphere, Springer, New York. 
Dove, M. (1988). The ecology of intoxication among the Kantu' of West Kalimantan. In Dove, M. (ed.), The Real and Imagined Role of Culture in Development: Case Studies from Indonesia, University of Hawaii Press, Honolulu, pp. 139-182.

Dow, G. F., and Edmonds, J. H. (1923). The Pirates of the New England Coast 1630-1730, Marine Research Society, Salem.

Earle, P. (1998). Sailors: English Merchant Seamen 1650-1775, Meuthen, London.

Garvin, D. B., and Garvin, J. L. (1988). On the Road North of Boston: New Hampshire Taverns and Turnpikes, 1700 1900, New Hampshire Historical Society, Concord.

Gennep, A. (1960). The Rites of Passage, University of Chicago Press, Chicago.

Glasse, H. (1774). The Art of Cookery, Made Plain and Easy, London.

Goodwin, L. (1999). An Archaeology of Manners: The Polite World of the Merchant Elite of Colonial Massachusetts, Kluwer Academic/Plenum Publishers, New York.

Gollannek, E. F. (2008). "Empire follows art": Exchange and the sensory worlds of empire in Britain and its colonies, 1740-1775. Doctoral dissertation, University of Delaware, Newark.

Governor, Council and Assembly of the Massachusetts Bay. (August 28, 1713). Letter. [Address of the Governor, Council and Assembly of the Massachusetts Bay to the Queen]. Colonial Office 5/751, Nos. 85, 85 i. Archival material.

Gregory, A. (1978). The Turks Islands salt trade and industry: An historical economic geography. Master's thesis, University of California Berkeley, Berkeley.

Grigsby, L. (2002). "Drink fair, don't swear": Winterthur's punch bowls and punch drinking in America. The Magazine Antiques 161(1): 176-183.

Harvey, K. (2012). Ritual encounters: Punch parties and masculinity in the eighteenth century. Past and Present 124(1): 165-203.

Harvey, K. (2008). Barbarity in a teacup? Punch, domesticity and gender in the eighteenth century. Journal of Design History 21(3): 205-219.

Hawdon, J. (2005). Drug and alcohol consumption as functions of social structures: a cross-cultural sociology, Edwin Mellen Press, New York.

Hume, I. N. (1969). A Guide to Artifacts of Colonial America, Alfred A. Knopf, New York.

Huntley, F. C. (1948). Salt: a Study in Colonial Economy. Master's thesis, University of California Berkeley, Berkeley.

Innis, H. A. (1940). The Cod Fisheries: the History of an International Economy, Yale University Press, New Haven.

Jankowiak, W. R., and Bradburd, D. (2003). Drugs, labor, and colonial expansion, University of Arizona Press, Tucson.

Jarvis, M. (2010a). In the Eye of All Trade: Bermuda, Bermudians, and the Maritime Atlantic World, 1680-1783, University of North Carolina Press, Chapel Hill.

Jarvis, M. (2010b). The binds of the anxious mariner: patriarchy, paternalism, and the maritime culture of eighteenth-century Bermuda. Journal of Early Modern History 14: 75-117.

Jarvis, M. (2002). Maritime masters and seafaring slaves in Bermuda, 1680-1783. The William and Mary Quarterly, Third Series, 59(3): 585-622.

Karp, I. (1980). Beer drinking and social experience in an African society: an essay in formal sociology. In Karp, I., and Bird, C. (eds.), Explorations of African Systems in Thought, Indiana University Press, Bloomington, pp. 83-119.

Kennedy, C. M. (2007). The other white gold: salt, slaves, the Turks and Caicos Islands and British colonialism. The Historian 69(2): 215-230.

King, J. A., and Miller, H. M. (1987). The view from the midden: an analysis of midden distribution and composition at the van Sweringen Site, St. Mary's City, Maryland. Historical Archaeology 21(2): 3759. 
Leone, M. (1999). Historical Archaeologies of Capitalism, Kluwer Academic/Plenum Press, New York.

Leone, M. (1988). The Recovery of Meaning: Historical Archaeology in the Eastern United States. Smithsonian Institution Press, Washington.

Ligon, R. (1673). A True \& Exact History of the Island of Barbadoes, London.

Lipski, L. L., and Archer, M. (ed). (1984). Dated English Delftware: Tin-Glazed Earthenware 1600-1800, Sotheby Publications, London.

Labat, R. P. (1979). Viajes a las Islas de La América, Casa de las Américas, La Habana.

Mack, J. (2011). The Sea: a Cultural History, Reaktion Books, London.

Maloney, N. J., and Macsotay, O. (1967). Geology of La Tortuga Island Venezuela. Boletín Informativo de la Asociación Venezolana de Geología, Minería y Petróleo 10(10): 266-287.

Minutes of His Majesty's Council, Bermuda, Oct. 7, 1766. (1996). Bermuda Journal of Archaeology and Maritime History 8: 200-227.

Nathan, G. R. (2006). Historic Taverns of Boston: 360 Years of Tavern History in One Definitive Guide. iUniverse.

Naval Officers' Lists of Shipping. (May 8, 1756). [Entry for Brigantine Elizabeth]. Colonial Office 5/969. Archival material.

Naval Officers' Lists of Shipping. (May 25 and 28, 1765). [Entries for Brigantine Somersworth and Schooner Sally]. Colonial Office 5/969. Archival material.

Pares, R. (1963). War and Trade in the West Indies, 1739-1763, Taylor \& Francis, London.

Political Register and Impartial Review of New Books. (1768). Third volume, H. Beevor, London.

Publications of the Colonial Society of Massachusetts (1927). Transactions, Volume 26, Colonial Society of Massachusetts, Boston.

Rediker, M. (1987). Between the Devil and the Deep Blue Sea: Merchants, Seamen, Pirates and the Anglo-American Maritime World, 1700-1750, Cambridge University Press, New York.

Rice, K. S. (1983). Early American Taverns: For the Entertainment of Friends and Strangers, Regnery Gateway, Chicago.

Rodger, N. A. M. (1986). The Wooden World: an Anatomy of the Georgian Navy, Naval Institute Press, Annapolis.

Ross, Lester A. (1983). Archaeological metrology: English, French, American and Canadian systems of weights and measures for North American archaeology, History and Archeology, Parks Canada, Ottawa.

Rudolph, W. (1985). Sailor Souvenirs: Stoneware, Faiences and Porcelain of Three Centuries, Edition Leipzig, Leipzig.

Sheldrake, P. (2001). Spaces for the Sacred: Space, Memory, and Identity, John Hopkins University Press, Baltimore.

Shlasko, E. (1989). Delftware chronology: a new approach to dating English tin-glazed ceramics. Master's thesis, College of William and Mary, Williamsburg.

Singleton, J. (2010). [1767] A General Description of the West Indian Islands, Gale ECCO.

Smith, F. H. (2001). Volatile spirits: the historical archaeology of alcohol and drinking in the Caribbean. Doctoral dissertation, University of Florida, Gainesville.

Smith, F. H. (2005). Caribbean Rum: A Social and Economic History, University Press of Florida, Gainesville.

Smith, F. H. (2008). The Archaeology of Alcohol and Drinking, University Press of Florida, Gainesville.

Smith, F. H., and Watson, K. (2008). Urbanity, sociability and commercial exchange in the Barbados sugar trade: a comparative colonial archaeological perspective on Bridgetown Barbados, in the seventeenth century. International Journal for Historical Archaeology 13:63-79. 
Suggs, D., and Lewis, S. (2003). Alcohol as a Direct and Indirect Labor Enhancer in the Mixed Economy of the BaTswana, 1800-1900. In Jankowiak, W., and Bradburd, D. (eds.), Drugs, Labor, and Colonial Expansion, University of Arizona Press, Tucson, pp. 135-148.

Tuan, Yi-Fu (1977). Space and Place: the Perspective of Experience, University of Minnesota Press, Minneapolis.

Turner, V. W. (1967). The Forest of Symbols: Aspects of Ndembu Ritual, Cornell University Press, Ithaca.

Turner, V. W. (1969). The Ritual Process: Structure and Anti-Structure, Aldine Publishing Company, Chicago.

Turner, V. W. (1974). Liminal to Liminoid, in Play, Flow, and Ritual: An Essay in Comparative Symbology. The Rice University Studies 60(3): 53-92.

Ward, B. M. (2012). The Moffatts of Portsmouth, New Hampshire, and the Caribbean. In Benes, P. (ed.), New England and the Caribbean, Dublin Seminar for New England Folklife Annual Proceedings 2008, pp. 59-73.

Watt, J. (1981). Some consequences of nutritional disorders in eighteenth-century British circumnavigations. In Watt, J., Freeman, E. J., and Bynum, W. F. (eds.), Starving Sailors: the Influence of Nutrition on Naval and Maritime History, National Maritime Museum, Bristol, pp. 5171.

Woodward, I. (2007). Understanding Material Culture, Sage Publications, London.

Wondrich, D. (2010). Punch: the Delights and Dangers of the Flowing Bowl, Penguin Group, New York.

Varela, M. J. (1980). Las Salinas de Araya y el Origen de la Armada de Barlovento, Biblioteca Nacional de la Historia, Caracas.

Vickers, D. (2005). Young Men and the Sea: Yankee Seafarers in the Age of Sail, Yale University Press, New Haven.

Viljoen, H., Lewis, M., and Van der Merwe, C. N. (2004). Introduction: Learning about space-and about ourselves. In Viljoen, H., and Van der Merwe, C. N. (eds.), Storyscapes: South African Perspectives on Literature, Space and Identity, Peter Lang Publishing, New York, pp. 1-24.

Yentsch, A. (1994). A Chesapeake Family and their Slaves: A Study in Historical Archaeology, Cambridge University Press, Cambridge, England.

Yentsch, A. (1991). Chesapeake artifacts and their cultural context: Pottery and the food domain. PostMedieval Archaeology 25: 25-72.

Yentsch, A. (1990). Minimum vessel lists as evidence of change in Folk and courtly traditions of food use. Historical Archaeology 24(3): 24-53. 